\title{
ВИДОВОЕ РАЗНООБРАЗИЕ И ДИНАМИКА АНТИБИОТИКОЧУВСТВИТЕЛЬНОСТИ ЭНТЕРОБАКТЕРИЙ, ВЫДЕЛЕННЫХ ОТ ЦЫПЛЯТ-БРОЙЛЕРОВ ИЗ ПРОМЫШЛЕННОГО СТАДА: 14-ЛЕТНИЕ ИССЛЕДОВАНИЯ*
}

\author{
М.В. КУЗНЕЦОВА, Е.В. АФАНАСЬЕВСКАЯ, М.О. ПОКАТИЛОВА, \\ А.А. КРУГЛОВА, Э.С. ГОРОВИЦ
}

Ограничение распространения и циркуляции антибиотикоустойчивых возбудителей бактериальных инфекций требует проведения санитарно-противоэпидемических, противоэпизоотических мероприятий, в том числе на предприятиях промышленного птицеводства. В настоящей работе впервые в сравнительном аспекте представлены данные многолетнего мониторинга распространенности и антибиотикоустойчивости энтеробактерий с комплексной оценкой эффективности основных ветеринарных препаратов, содержащих фторхинолоны и колистин. Нашей целью было изучение видового разнообразия и сравнительная оценка антибиотикоустойчивости штаммов энтеробактерий, выделенных от цыплят-бройлеров (Gallus gallus) в крупном птицеводческом комплексе (АО «ПРОДО Птицефабрика Пермская», Пермский край). Исследовали патологический материал от птицы после вынужденного убоя (трахея, легкие, сердце, печень, селезенка, костная ткань - бедренная и большеберцовая кости) и эмбрионов-задохликов (в 2004-2009 годах 995 проб, в 2010-2017 годах 991 проба). Контролем служили органы здоровых цыплят-бройлеров кросса Ross 308. В серии специальных экспериментов определяли эффективность применяемых в указанном хозяйстве ветеринарных препаратов в отношении некоторых возбудителей. Установлено, что высеваемость бактерий семейства Enterobacteriaceae во все сроки наблюдения оставалась стабильно высокой и значительно превышала аналогичный показатель для грамположительных микроорганизмов (р < 0,00001). В 2010-2017 годах оказалась достоверно выше обсемененность сердца $($ p $<0,05)$ и селезенки $($ p $<0,01)$, а инфицированность эмбрионов-задохликов составила $25 \%$ и была ниже $($ p $<0,05)$ таковой в 2004-2009 годах. По частоте встречаемости доминировала Escherichia coli (субдоминантный вид - Proteus mirabilis). Доля птичьих патогенных $E$. coli (avian pathogenic $E$. coli, APEC) в общем микробном спектре не изменилась, протея увеличилась $(\mathbf{p}<0,0001)$, а сальмонелл - снизилась $(\mathbf{p}<0,05)$, встречаемость других представителей энтеробактерий статистически значимо не различалась. Выявлены разнонаправленные тенденции в распространенности антибиотикоустойчивых культур $E$. coli: число резистентных к ципрофлоксацину штаммов возросло с 47,4 до 75,9\% (p < 0,0005), к амикацину - снизилось с 32,8 до $16,4 \%$ (р < 0,0001). Из четырех исследованных ветеринарных колистиносодержащих препаратов наибольшей активностью обладал Колифлокс (ООО «НВЦ Агроветзащита С-П.», Россия), представленный комбинацией колистина в максимальной дозе и энрофлоксацина. Далее по убыванию шел Витроцил (Vitrocil, «Interchemie werken De Adelaar B.V.», Нидерланды), который содержит в 10 раз меньше колистина и в 2 раза меныше энрофлоксацина, Пульмосол® (ООО «ВИК - здоровье животных», Беларусь) и Акваприм (Aquaprim, «S.P. Veterinaria, S.A.», Испания) с колистином в дозе соответственно 1,1 млн и 400000 МЕ. Два последних препарата, не имеющие в составе фторхинолонов, показали наименьшую активность: к ним были устойчивы 37,5 и 35,7 \% культур E. coli, 50,0 и 37,5 \% культур Proteus spp. Таким образом, наибольшей активностью в отношении энтеробактерий обладали комбинированные ветеринарные препараты, содержащие энрофлоксацин, но их эффективность в последние годы снизилась. Длительное применение в качестве кормовых добавок фторхинолонов для профилактики инфекций у птицы, повидимому, становится фактором риска, приводящим к селекции устойчивых к ним штаммов.

Ключевые слова: птицеводческое хозяйство, мониторинг, энтеробактерии, Escherichia coli, антибиотикоустойчивость.

Бактериальные инфекции занимают второе место после вирусных и наносят ощутимый ущерб промышленному птицеводству во всем мире, поскольку смертность птицы от них может составлять до $35 \%$ (1). Эта проблема приобретает особую актуальность в связи с увеличением числа заболеваний, передающихся через пищевые продукты $(2,3)$. Обеспечение эффективной защиты сельскохозяйственной птицы от инфекционной па-

* Исследование выполнено при финансовой поддержке Правительства Пермского края в рамках научного проекта № C-26/792. 
тологии было и остается одной из основных задач ветеринарии $(4,5)$.

Условия крупных птицеводческих хозяйств с высокой плотностью посадки поголовья обусловливают циркуляцию среди птиц и людей различных видов микроорганизмов, создавая угрозу вспышек заболеваний. Животные могут быть источником патогенных и условно-патогенных бактерий - Salmonella enterica, Escherichia coli, Proteus vulgaris, Pseudomonas aeruginosa, Staphylococcus aureus (6-9). Грамотрицательные бактерии, как правило, вызывают острое течение заболеваний. Для их лечения и профилактики используют одни и те же химические препараты в течение длительного времени. Это приводит к распространению антибиотикоустойчивых штаммов микроорганизмов, в первую очередь энтеробактерий, которые становятся основным депо генов антибиотикорезистентности. E. coli уже практически полностью нечувствительна к тетрациклинам и налидиксовой кислоте (10). V.L. Koga с соавт. (11) выявили значительное число изолятов E. coli, продуцирующих $\beta$-лактамазы расширенного спектра действия (БЛРС, extended-spectrum $\beta$-lactamase, ESBL). У сальмонелл, выделенных от птиц, часто обнаруживается множественная устойчивость к антибактериальным препаратам $(8,12,13)$. Описаны устойчивые к фторхинолонам виды энтеробактерий, циркулирующие на птицеводческих предприятиях $(14,15)$.

Известно, что инфицированность поголовья бактериями, их видовая принадлежность и антибиотикоустойчивость в разных птицеводческих хозяйствах существенно различаются. Контроль возбудителей бактериальных инфекций необходим для оценки эпизоотической ситуации на птицефабриках и подбора активных антибактериальных препаратов. Кроме того, поскольку большинство антибиотиков, используемых в промышленном птицеводстве, применяется и в медицине, представляет интерес анализ распространенности и профилей устойчивости к ним энтеробактерий, встречающихся в птицеводческих хозяйствах.

В настоящем исследовании впервые в сравнительном аспекте представлены данные многолетнего мониторинга распространенности и антибиотикоустойчивости энтеробактерий с комплексной оценкой эффективности основных ветеринарных препаратов, содержащих фторхинолоны и колистин. Установлено, что высеваемость бактерий семейства Enterobacteriaceae из органов птиц значительно превышала аналогичный показатель для грамположительных микроорганизмов, кроме того, увеличилось число генерализованных форм колибактериоза. Препараты, содержащие энрофлоксацин, обладали наибольшей активностью в отношении энтеробактерий, но в результате длительного использования для антибактериальной терапии на объектах промышленного птицеводства их эффективность снизилась.

Цель работы заключалась в изучении видового разнообразия и сравнительной оценке антибиотикоустойчивости штаммов энтеробактерий, выделенных от цыплят-бройлеров в крупном птицеводческом комплексе.

Методика. Исследовали патологический материал от цыплят-бройлеров (Gallus gallus) (кросс Ross 308; АО «ПРОДО Птицефабрика Пермская», Пермский край) после вынужденного убоя (трахея, легкие, сердце, печень, селезенка, костная ткань - бедренная и большеберцовая кости) и эмбрионов-задохликов. Всего протестировали 995 проб в 2004-2009 годах (16) и 991 пробу в 2010-2017 годах. Контролем служили органы здоровой птицы. Материал отбирали ежемесячно. Возраст птицы варьировал

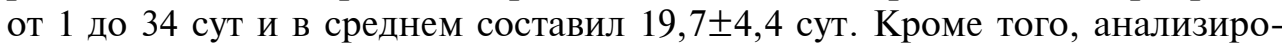
вали пробы воды из системы поения (как вероятный источник инфицированности птицы). 
Бактериологические исследования выполняли традиционным методом. Материал отбирали стерильно и засевали по Гольду на среду МакКонки («Sigma», США) и кровяной агар. Выделенные культуры идентифицировали до вида с использованием диагностических систем Enteroest16 и NefermTest24 («Lachema», Чехия). Чувствительность изолированных штаммов к антибактериальным препаратам определяли диско-диффузионным методом согласно МУК 4.2.1890-04. Использовали агар Мюллера-Хинтон («Merk», США) и коммерческие диски производства «ООО НИЦФ» (Санкт-Петербург, Россия) или «HiMedia Laboratories Pvt. Ltd.» (Индия), содержащие следующие антибиотики (мкг): ампициллин - 10, амоксициллин-клавуланат $-20 / 10$, цефотаксим - 5, меропенем - 10, гентамицин -10 , амикацин - 30, ципрофлоксацин -5 , левофлоксацин -5 , хлорамфеникол - 30, тетрациклин - 30, налидиксовая кислота - 30 и фуразолидон - 50. Внутренним контролем служил референтный штамм Escherichia coli ATCC 25922.

В серии специальных экспериментов определяли эффективность применяемых в указанном хозяйстве ветеринарных препаратов в отношении некоторых возбудителей бактериальных болезней птиц. Оценивали следующие препараты: Акваприм (Aquaprim, «S.P. Veterinaria, S.A.», Испания), Витроцил (Vitrocil, «Interchemie werken De Adelaar B.V.», Нидерланды), Колифлокс (ООО «НВЦ Агроветзащита С-П.», Россия), Пульмосол® (ООО «ВИК - здоровье животных», Беларусь), Трифлон (ООО «Витавет», Россия), Ципровет (ООО «НВЦ Агроветзащита С-П.», Россия), Энрофлон (ООО «ВИК - здоровье животных», Беларусь). Все препараты входят в «Реестр лекарственных средств и кормовых добавок для животных», разрешенных к использованию в России, относятся к III или IV классу опасности по ГОСТ 12.1.007-76 (за исключением Трифлона, II класс опасности) и назначаются цыплятам-бройлерам с лечебной и лечебно-профилактической целью. Их эффективность оценивали методом серийных разведений. Разведения готовили с учетом рабочей дозы препарата согласно инструкции производителя.

Статистическую обработку полученных данных проводили с использованием компьютерных программ Microsoft Excel 2016 и STATISTICA 10 («StatSoft, Inc.», США). Показатели представлены в виде среднего арифметического и его ошибки ( $M \pm \mathrm{SEM})$. Для выявления статистически значимых различий двух независимых выборок определяли $\chi^{2}$ (хи-квадрат) или $\chi^{2}$ с поправкой Йейтса (Frank Yates).

Результаты. Во все сроки наблюдения высеваемость грамотрицательных микроорганизмов из органов цыплят-бройлеров после вынужденного убоя оставалась высокой (рис. 1). В 2012-2014 годах отмечали некоторое снижение показателя обсемененности, но с 2015 года он снова превышал 50 \% от всех исследованных проб. Несмотря на то, что в последние годы также отмечается рост инфицированности птицы грамположительными микроорганизмами, в 2010-2017 годах частота проб с грамотрицательными бактериями $(59,0 \%)$, значительно превышала аналогичный показатель для грамположительных $(14,4$ \%) (р < 0,00001). В целом в 20042009 и 2010-2017 годах средние показатели инфицированности птицы бактериальной микрофлорой статистически значимо не различались (соответ-

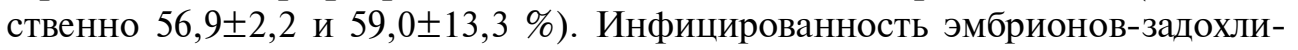
ков на втором этапе исследования составила $25 \%$ и была ниже таковой по сравнению с выявленной в 2004-2009 годы ( $=0,0462)$.

В воде из системы поения энтеробактерии изолировали более чем в 


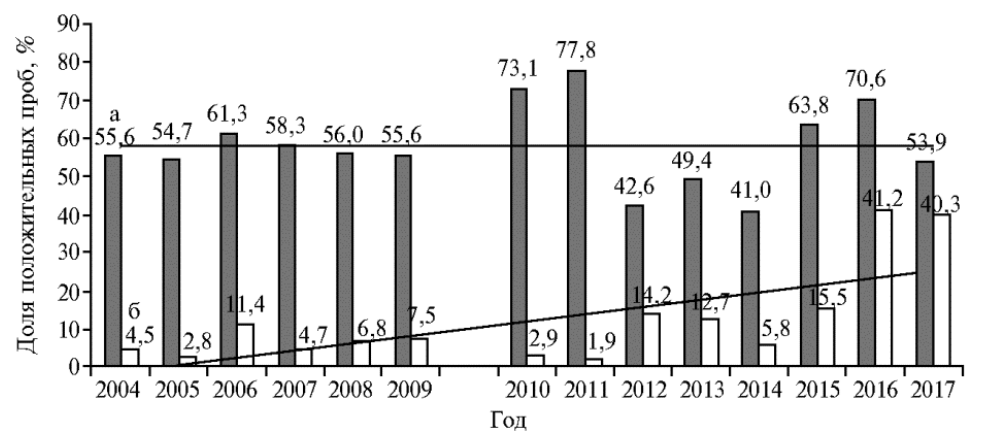

Рис. 1. Показатели микробной обсемененности внутренних органов цыплят-бройлеров (Gallus gallus) кросса Ross 308 грамотрицательными (а) и грамположительными (б) бактериями по данным за 2004-2009 годы (16) и в 2010-2017 годах (АО «ПРОДО Птицефабрика Пермская», Пермский край). Прямые отражают тенденции в изменении представленности для каждой группы микроорганизмов.

Трахея, легкие, сердце, печень, селезенка и костная ткань бройлеров были инфицированы грамотрицательными бактериями соответственно в 31,$2 ; 73,1 ; 64,3 ; 62,5 ; 65,7$ и 32,3 \% случаев (табл. 1 ). Из костной ткани бактерии изолировали реже, чем из паренхиматозных органов и легких $(\mathrm{p}<0,0001)$. Статистически достоверных различий между инфицированностью сердца, печени и селезенки не выявили. Трахея была инфицирована меньше, чем легкие $(\mathrm{p}<0,0005)$, которые оказались наиболее обсемененными из всего исследованного материала. По сравнению с 20042009 годами показатели бактериальной обсемененности сердца $(\mathrm{p}<0,05)$ и селезенки $(\mathrm{p}<0,01)$ были достоверно выше.

1. Обсемененность грамотрицательными бактериями внутренних органов эмбрионов, цыплят-бройлеров (Gallus gallus) кросса Ross 308 и воды из системы поения в разные годы (АО «ПРОДО Птицефабрика Пермская», Пермский край)

\begin{tabular}{|c|c|c|c|c|c|c|}
\hline \multirow[b]{2}{*}{ Источник } & \multirow[b]{2}{*}{ № } & \multirow[b]{2}{*}{ Орган, биотоп } & \multicolumn{2}{|c|}{ 2004-2009 годы (16) } & \multicolumn{2}{|c|}{ 2010-2017 годы } \\
\hline & & & $\begin{array}{l}\text { число проб, } \\
n\end{array}$ & $\begin{array}{l}\text { положительные } \\
\text { пробы, } n(\%)\end{array}$ & $\begin{array}{l}\text { число проб, } \\
n\end{array}$ & $\begin{array}{l}\text { положительные } \\
\text { пробы, } n(\%)\end{array}$ \\
\hline \multirow[t]{12}{*}{ Бройлеры } & 1 & Трахея & - & - & 16 & $5(31,2 \%)$ \\
\hline & 2 & Легкие & 6 & $5(83,3 \%)$ & 104 & $76(73,1 \%)$ \\
\hline & & & & & & $\mathrm{p}_{1-2}<0,0005$ \\
\hline & 3 & Сердце & 264 & $143(54,2 \%)$ & 244 & $157(64,3 \%)$ \\
\hline & 4 & Печень & 276 & $186(67,4 \%)$ & 307 & $192(62,5 \%)$ \\
\hline & & & & $\mathrm{p}_{3-4}<0,01$ & & \\
\hline & 5 & Селезенка & 180 & $90(50 \%)$ & 134 & $88(65,7 \%)$ \\
\hline & 6 & Костная ткань & - & $\begin{array}{c}\mathrm{p}_{4-5}<0,01 \\
-\end{array}$ & 155 & $\begin{array}{c}50(32,3 \%) \\
\mathrm{p}_{2-6}<0,0001 \\
\mathrm{p}_{3-6}<0,0001 \\
\mathrm{p}_{4-6}<0,0001 \\
\mathrm{p}_{5-6}<0,0001\end{array}$ \\
\hline & 7 & Почки & - & - & 12 & 0 \\
\hline & 8 & Яичник & 110 & $64(58,2 \%)$ & - & - \\
\hline & 9 & Другие органы & 10 & $6(60 \%)$ & 3 & $2(66,7 \%)$ \\
\hline & 10 & Все органы & 846 & $494(58,4 \%)$ & 975 & $570(58,5 \%)$ \\
\hline Эмбрионы & 11 & & 149 & $75(50 \%)$ & 16 & $4(25 \%)$ \\
\hline Система поения & 12 & Вода & 142 & $124(87,3 \%)$ & 15 & $\begin{array}{c}\left.\mathrm{p}_{10-11<0,05}<0,86,6 \%\right) \\
13(86,6)\end{array}$ \\
\hline
\end{tabular}

П р и м е ч а н и е. Прочерки означают отсутствие данных в указанный период. Нижние индексы при $\mathrm{p}-$ номера сравниваемых образцов.

Ожидаемо инфицированность птицы $E$. coli преобладала на протя-

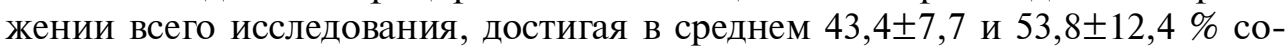
ответственно за 2004-2009 и 2010-2017 годы (см. рис. 2, А). Среди энтеробактерий удельный вес эшерихий составлял 63,3 \% в 2004-2009 годах, 
69,6 \% - в последующий период и достоверно не различался (см. рис. 2, Б). Доля протеев (Proteus mirabilis, P. vulgaris и др.) варьировала от 7,4 \% в 2006 году до 45,7 \% в 2016 году и в среднем за последние 8 лет составила $22,8 \%$, что было почти в 2 раза больше, чем в 2004-2009 годах - 12,2\% ( $<0,0001)$. Отмечался высокий показатель инфицированности птицы сальмонеллами $(26,6$ \%) в 2009 году со значительной долей изолятов эмбрионального происхождения. В 2010-2017 годах их удельный вес оказался достоверно меньше, чем в предыдущий период. В целом за 2010-2017 годы видовое разнообразие энтеробактерий, выделенных из материала от птицы после вынужденного убоя, существенно не изменилось в сравнении с 2004-2009 годами, при этом мы выявили достоверное увеличение доли представителей рода Proteus, тенденцию к увеличению инфицированности птицы эшерихиями и, что существенно важно, снижение частоты сальмонелл, в том числе в эмбриональном материале.

A

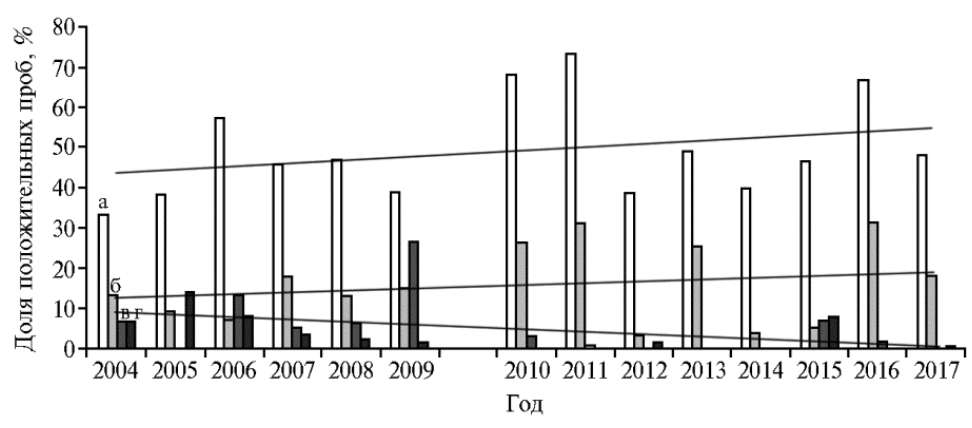

Б

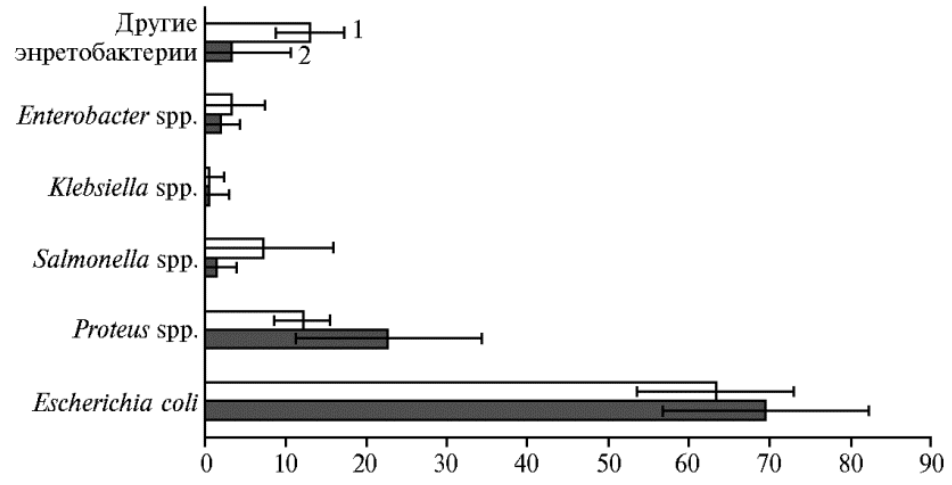

Рис. 2. Инфицированность энтеробактериями цыпля-бройлеров (Gallus gallus) кросca Ross 308 (А) и удельный вес (\%) энтеробактерий (Б) в разные годы: a - Escherichia coli, б - Proteus spp., в - Salmonella spp., г - другие энтеробактерии; 1 - 2004-2009 (16), 2 - 2010-2017 годы. В группу Proteus spp. вошли P. mirabilis, P. vulgaris; в группу Salmonella spp. - Salmonella cеровар Enteritidis, S. tiphimurium, S. arizonae и др.; в группу Klebsiella spp. - K. pneumoniae, K. oxytoca; в группу Enterobacter spp. - E. sakazakii, E. aerogenes, E. cloacae; в группу других энтеробактерий - Escherichia vulneris, Citrobacter freundii, Morganella morganii (АО «ПРОДО Птицефабрика Пермская», Пермский край). Прямые отражают тенденции в изменении представленности для каждой группы микроорганизмов.

Поскольку на протяжении всего срока наблюдения доминирующими бактериями были E. coli и Proteus spp., мы изучили антибиотикочувствительность именно этих микроорганизмов с использованием дискодиффузионного метода. Было проанализировано 511 штаммов эшерихий и 172 штамма протея. При выборе тестируемых антибактериальных препаратов учитывали как длительность их использования в ветеринарной практике, так и видовые особенности изолятов. Удельный вес резистентных 
или условно-резистентных к ампициллину и цефотаксиму штаммов $E$. coli среди выделенных в 2010-2017 годах составил соответственно 74,1 и 17,8 \% (табл. 2). Как и на первом этапе исследования (в 2004-2009 годах), к меропенему были чувствительны все бактерии. Резистентность к амикацину варьировала от 5,9 до $34,9 \%$ и в среднем за 8 лет составила $16,4 \%$, что статистически достоверно меньше, чем в предыдущий период (p < 0,0001). Схожие тенденции выявили для гентамицина: в 2010 году доля устойчивых к гентамицину штаммов E. coli достигала почти 60,0 \%, а в 2017 году только 6,2 \%. Резистентности бактерий к ципрофлоксацину, наоборот, статистически значимо увеличивалась до отметки 75,9 \% во второй период исследования (р < 0,0005). Число штаммов E. coli, устойчивых к левофлоксацину, оказалось ниже, но все равно на них приходилось около половины культур. Для протея прослеживали сходные тенденции: была выявлена значительная доля штаммов, устойчивых к ампициллину $(42,5 \%)$ и фторхинолонам - ципрофлоксацину (36,8 \%) и норфлоксацину $(33,4 \%)$, тогда как устойчивых к гентамицину и амикацину оказалось существенно меньше - соответственно 20,2 и 2,1 \%. К фуразолидону, тетрациклину и налидиксовой кислоте были нечувствительны практически все культуры исследованных энтеробактерий.

2. Антибиотикоустойчивость изолятов Escherichia coli (абсолютное число устойчивых/\%), выделенных из внутренних органов цыплят-бройлеров (Gallus gallus) кросса Ross 308 в разные годы (АО «ПРОДО Птицефабрика Пермская», Пермский край)

\begin{tabular}{l|c|c}
\hline \multicolumn{1}{c}{ Антибактериальный препарат } & $2004-2009$ годы $(n=390)(16)$ & $2010-2017$ годы $(n=511)$ \\
\hline Ампициллин & $321 / 82,3$ & $379 / 74,1$ \\
Амоксиклав & $181 / 46,4$ & - \\
Цефотаксим & $87 / 22,3$ & $91 / 17,8$ \\
Меропенем & 0 & 0 \\
Гентамицин & $212 / 48,9$ & $54 / 10,6^{*}$ \\
Амикацин & $128 / 32,8$ & $84 / 16,4 *$ \\
Ципрофлоксацин & $185 / 47,4$ & $388 / 75,9 *$ \\
Левофлоксацин & - & $221 / 43,2$ \\
Хлорамфеникол & $208 / 53,3$ & - \\
Тетрациклин & $385 / 98,7$ & $443 / 86,7$ \\
Налидиксовая кислота & - & $459 / 89,8$ \\
Фуразолидон & $359 / 2,1$ & $476 / 93,1$ \\
П р и м е ч н и е. Прочерки означают отсутствие данных в указанный период. \\
* Различия с предыдущим периодом статистически значимы при р < $0,05$.
\end{tabular}

В специальной серии экспериментов изучили эффективность семи ветеринарных препаратов в отношении основных возбудителей бактериальной инфекции птиц - E. coli, Proteus spp. и Salmonella cepoвap Enteritidis. Из четырех исследованных колистиносодержащих препаратов наибольшей активностью обладал Колифлокс, представленный комбинацией колистина в максимальной дозе и энрофлоксацина (табл. 3). Далее по убыванию следовали Витроцил, который содержал в 10 раз меньше колистина и в 2 раза - энрофлоксацина, Пульмосол® и Акваприм (доза колистина соответственно 1,1 млн МЕ и 400000 МЕ). Два последних препарата, не имеющие в своем составе фторхинолонов, в рабочей дозе показали наименышую активность: к ним были устойчивы 37,5 и 35,7 \% культур E. coli, 50 и $37,5 \%$ культур Proteus spp.

Монопрепараты, содержащие фторхинолоны, подавляли рост более $80 \%$ всех протестированных энтеробактерий. Энрофлон оказался статистически не значимо, но более эффективным, чем Ципровет, в первую очередь за счет действия на штаммы протея. При этом Трифлон, в котором присутствует еще и триметаприм, был менее активен в отношении протея, чем Энрофлон, но это может быть связано с меньшей выборкой 
культур. Все культуры Salmonella серовар Enteritidis $(n=3)$ были чувствительны к исследованным комбинированным ветеринарным препаратам в рабочей дозе. Необходимо отметить, что в большинстве случаев рост бактерий ингибировался при разведении препаратов в дозе меньше рабочей в 2 раза, например при тестировании Колифлокса (данные не представлены). При этом рост обеих культур, резистентных к Колифлоксу в рабочей дозе, подавлялся препаратом, добавленным в двойной дозе. Аналогичные данные получены и для остальных протестированных препаратов. Энтеробактерии были устойчивы и к повышенной концентрации препарата, а их число увеличивалось в динамике: для Акваприма таких культур было 7 из 9 (77,7 \%; 1 культура в 2015 году и 6 - в 2017 году), для Витроцила - 6 из 10 (60\%; все культуры выделены в 2017 году), для Пульмосола® ${ }^{\circledR}-11$ из 21 (52,4 \%; 3 культуры в 2015 году и 8 культур в 2017 году), для Ципровета - 5 из 11 резистентных культур (45,4 \%; все культуры выделены в 2017 году).

3. Резистентность изолятов Escherichia coli и Proteus spp., выдленных из внутренних органов цыплят-бройлеров (Gallus gallus) кросса Ross 308, к некоторым ветеринарным препаратам (АО «ПРОДО Птицефабрика Пермская», Пермский край)

\begin{tabular}{|c|c|c|c|c|c|c|c|}
\hline \multirow{3}{*}{$\begin{array}{l}\text { Препарат (рабочая } \\
\text { доза), активное } \\
\text { вещество }\end{array}$} & \multirow{3}{*}{$\begin{array}{l}\text { Количество ак- } \\
\text { тивного вещества }\end{array}$} & \multicolumn{6}{|c|}{ Число штаммов, $n / \%$} \\
\hline & & \multicolumn{2}{|r|}{ E. coli } & \multicolumn{2}{|c|}{\begin{tabular}{|l|} 
Proteus spp. \\
\end{tabular}} & \multicolumn{2}{|c|}{ энтеробактерии } \\
\hline & & всего & устойчивые & всего & устойчивые & всего & устойчивые \\
\hline \multicolumn{8}{|l|}{ Акваприм (1 мл/л): } \\
\hline линкомицин & 50 мг & & & & & & \\
\hline сульфаметоксол & 200 мг & & & & & & \\
\hline триметоприм & $20 \mathrm{м \Gamma}$ & & & & & & \\
\hline колистин & $400000 \mathrm{ME}$ & 16 & $6 / 37,5$ & 6 & $3 / 50,0$ & 22 & $9 / 40,9$ \\
\hline \multicolumn{8}{|l|}{ Витроцил $(0,5$ мл/л): } \\
\hline колистин & $600000 \mathrm{ME}$ & 24 & $8 / 33,3$ & 11 & $2 / 18,2$ & 35 & $10 / 28,6$ \\
\hline \multicolumn{8}{|l|}{ Колифлокс (1 мл/л): } \\
\hline $\begin{array}{l}\text { энрофлоксацин } \\
\text { колистин }\end{array}$ & $\begin{array}{c}100 \text { мГ } \\
7 \text { млн МЕ }\end{array}$ & 12 & $1 / 8,3$ & 5 & $1 / 20,0$ & 17 & $2 / 11,8$ \\
\hline \multicolumn{8}{|l|}{ Пульмосол® (150 г/л): } \\
\hline $\begin{array}{l}\text { китасамицин } \\
\text { колистин }\end{array}$ & $\begin{array}{c}52,5 \text { мг } \\
1,1 \text { млн МЕ }\end{array}$ & 42 & $15 / 35,7$ & 16 & $6 / 37,5$ & 58 & $21 / 36,2$ \\
\hline $\begin{array}{l}\text { Трифлон (1 мл/л): } \\
\text { энрофлоксацин } \\
\text { триметоприм }\end{array}$ & $\begin{array}{r}100 \mathrm{Mг} \\
50 \mathrm{M \Gamma}\end{array}$ & 5 & r & 2 & $1 / 500$ & 7 & $1 / 143$ \\
\hline Ципровет (1 г/л): & & 3 & 0 & 2 & $1 / 30,0$ & 1 & $1 / 14,3$ \\
\hline $\begin{array}{l}\text { ципрофлоксацин } \\
\text { Энрофлон (1 г/л): }\end{array}$ & 100 мг & 39 & $6 / 15,3$ & 18 & $4 / 22,2$ & 57 & $10 / 17,5$ \\
\hline энрофлоксацин & 100 мг & 53 & $8 / 15,1$ & 25 & $3 / 12,0$ & 78 & $11 / 14,1$ \\
\hline
\end{tabular}

Данные ежегодной медицинской статистики демонстрируют, что бактерии родов Salmonella, Escherichia и Campylobacter оказываются наиболее частыми возбудителями антропозоонозов, которые ассоциируются с продуктами птицеводства. Само по себе промышленное содержание птицы служит мощным стрессорным фактором, модулирующим реакции врожденного и приобретенного иммунитета, снижающим резистентность птиц даже к собственной микробиоте, что создает предпосылки для воздействия бактерий на организм и быстрого распространения возбудителей болезней. В последние годы в птицеводческих хозяйствах возросла циркуляция условно-патогенных и патогенных микроорганизмов, которые могут быть причиной пищевых отравлений человека (17-19). Необходимость исследования динамики распространения антибиотикорезистентности у представителей семейства Enterobacteriaceae не вызывает сомнения.

Известно, что в специализированных птицеводческих хозяйствах 
России на протяжении многих лет гибель птицы от коли-инфекции остается высокой (20). Так, по данным Всероссийского научно-исследовательского ветеринарного института птицеводства (г. Санкт-Петербург), удельный вес E. coli, выделенных в последнее годы от различных видов птиц в нескольких регионах России, составляет не менее 40 \% (21). Микробиологический мониторинг на 11 птицефабриках Западной Сибири позволил установить доминирование E. coli среди грамотрицательных микроорганизмов (48 \%). Представителей родов Citrobacter и Proteus изолировали только в 13 и $6 \%$ случаев (22). В нескольких птицеводческих хозяйствах Украины эшерихии составили 30,8 \% в микробиоте павшей птицы (23).

Наиболее важная проблема для всей коммерческой домашней птицы - системная коли-инфекция, а также респираторные заболевания, такие как аэросаккулит $(20,24)$. В многоцентровом мониторинговом исследовании, проведенном А.Н. Калининым и соавт. (25), показано, что при респираторном синдроме птиц грамотрицательная флора выделялась в большинстве случаев: E. coli - 36,5\%, P. vulgaris - 11,7 \%, P. aeruginosa 5,8 \%, Salmonella серовар Enteritidis - 3,9\%. В нашей работе выявлено, что инфицированность птицы E. coli превалировала, а удельный вес эшерихий среди энтеробактерий был стабильно выше $60 \%$. Отмечена преобладающая доля E. coli при инфицировании всех органов и тканей. Так, E. coli изолировали из сердца в 80,3 \% случаев, что совпадает с фактом, что фибринозный перикардит - наиболее типичный признак колибактериоза (21).

В процессе инкубации и выращивания птицы увеличивается количественный и видовой состав микрофлоры, который достигает максимума при выводе (22). Действительно, эмбрионы, исследованные нами, были менее инфицированы, чем цыплята-бройлеры. Ранее при 6-летнем наблюдении за развитием птиц в динамике от 1-х до 43-45-х сут мы показали, что инфицирование определяется возрастом птицы (16). Если у 1-суточных цыплят внутренние органы были практически стерильными, то к 40-м сут их бактериальная обсемененность достигала 78,3\%.

Проблема антимикробной резистентности за последние 20 лет приобрела особое значение в связи с интенсификацией сельского хозяйства. На 68-й сессии Всемирной ассамблеи здравоохранения принят Глобальный план мероприятий по снижению устойчивости микроорганизмов к противомикробным препаратам (резолюция WHA68.7 от 26 мая 2015 года). Комплексный и межсекторальный подход, который предусматривает создание системы контроля за оборотом антибиотиков, предлагается для отраслей, где они активно используются, в том числе для сельского хозяйства.

В разные годы показатели антибиотикоустойчивости штаммов E. coli на птицеводческом предприятии Пермского края к одним из рассмотренных нами препаратов варьировали в широких пределах, к другим были относительно стабильными. При этом необходимо отметить, что с 2011 года в корма антибиотики не добавляли. Так, резистентность штаммов к ампициллину, тетрациклину, фуразолидону и налидиксовой кислоте почти не менялась, и устойчивость к этим препаратам можно рассматривать как закрепившийся признак, что, по-видимому, связано с длительным применением перечисленных химиопреператов на птицефабрике. Тем не менее удалось выявить динамику изменения устойчивости штаммов к аминогликозидам и фторхинолонам. В первом случае количество изолируемых от птиц резистентных штаммов статистически значимо снизилось, что, вероятно, связано с полным прекращением использования этих препаратов с 2013 года, способствующим элиминации таких культур из экосистемы. По- 
лученные результаты свидетельствуют о том, что ротация антибиотиков может быть эффективной для борьбы с резистентными штаммами.

Устойчивость к фторхинолонам, напротив, существенно возросла, что может быть связано с длительным использованием монокомпонентных и комплексных фторхинолоносодержащих препаратов (Энроксил, Ципровет, Энрофлон, Гидроквинокол, Колифлокс, Квиноприм, Трифлон). Действующее вещество большинства из них - энрофлоксацин, который частично метаболизируется в печени с образованием ципрофлоксацина и подавляет бактериальную ДНК-гиразу и топоизомеразу IV. При этом наибольшую антимикробную активность (при оценке методом серийных разведений) проявляли именно фторхинолоносодержащие препараты, хотя и их эффективность начала постепенно снижаться.

Наши данные в отношении эффективности ряда препаратов согласуются с исследованиями других авторов. Так, в работе T.D. Miles и соавт. (10) установлено, что штаммы $E$. coli, изолированные от цыплят, в 82,4 \% случаев устойчивы к тетрациклину, в 85,3 \% - к налидиксовой кислоте и только в 8,8 \% - к ципрофлоксацину. При этом почти 30 \% были устойчивы и около $40 \%$ умеренно устойчивы к энрофлоксацину. В другой работе проверка чувствительности энтеробактерий к 15 лекарственным средствам показала, что результативным были аминогликозиды, неомицин и гентамицин, а к остальным препаратами, в том числе фторхинолонового ряда (энрофлокс, энрофлон), оказались устойчивы большинство эшерихий (19). T.R. Thorsteinsdottir с соавт. (26) обнаружили, что резистентные к энрофлоксацину штаммы E. coli встречались в 33,6 \% случаях при скрининге изолятов от цыплят-бройлеров и в 52 \% - при скрининге пищевых продуктов (мясо бройлеров). В Иране среди 318 штаммов APEC (avian pathogenic E. coli), изолированных от цыплят-бройлеров с генерализованной коли-инфекцией, 37,7 \% оказались устойчивы к энрофлоксацину, но только $7,5 \%$ - к ципрофлоксацину и 5,7 \% - к гентамицину (27). По данным проверки ветеринарных препаратов в рамках микробиологического мониторинга на птицеводческих хозяйствах Украины выявлена высокая бактерицидная активность фторхинолонов - энроксила и сарафлоксацина (22). Обсервационное исследование на федеральных заводах по переработке птицы в Канаде показало, что в куриных стадах все штаммы E. coli были чувствительны к амикацину, ципрофлоксацину и энрофлоксацину, однако необходимо отметить, что эти данные получены в 2003-2004 годах (28).

Следовательно, тенденция к увеличению количества антибиотикоустойчивых штаммов бактерий характерна для разных стран. Показана связь между применением конкретных препаратов на предприятиях птицеводства и резистентностью к ним циркулирующих бактерий (28). В большинстве сообщений отмечается практически полная устойчивость APEC к тетрациклину, опосредованная присутствием эффлюкс-генов tetB и tet $D$, которые часто ассоциируются с конъюгативными плазмидами (10). При этом сохраняется достаточно высокая чувствительность к аминогликозидам. Данные в отношении хинолонов и фторхинолонов противоречивы: в значительной части исследований описывается высокая устойчивость к налидиксовой кислоте, но доля штаммов, резистентных к ципрофлоксацину и энрофлоксацину, может существенно различаться. Доказано, что изоляты, устойчивые к фторхинолонам, могут циркулировать даже при отсутствии дальнейшего воздействия препарата, в связи с чем некоторые страны отказались от использования фторхинолонов в птицеводстве (29). Активно обсуждается вопрос о перспективе применения колистина (группа полимиксина): во-первых, из-за нарастающей устойчивости в свя- 
зи с распространением гена $m c r-1$ возможны сбои при лечении колибактериоза и сальмонеллеза у животных, во-вторых, в медицине необходимо поддерживать эффективность препаратов последней инстанции для борьбы с возбудителями бактериальных инфекций с множественной лекарственной устойчивостью (30). Обеспечение системного мониторинга распространения антимикробной резистентности стало частью программы «Стратегия предупреждения распространения антимикробной резистентности в Российской Федерации на период до 2030 года» (распоряжение Правительства РФ № 2045-р от 25 октября 2017 года).

Таким образом, нами был проведен мониторинг энтеробактерий, представленных в микробиоте цыплят-бройлеров в крупном птицеводческом хозяйстве Пермского края. Установлено, что высеваемость энтеробактерий из органов птицы во все сроки наблюдения оставалась стабильно высокой и значительно превышала аналогичный показатель для грамположительных микроорганизмов. В 2004-2009 и 2010-2017 годах средние показатели инфицированности органов птицы грамотрицательными

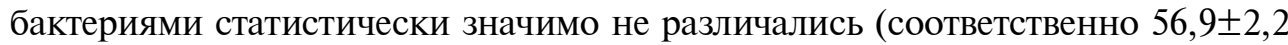

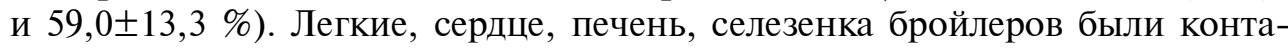
минированы более чем в 50 \% случаев, трахея и костная ткань - у каждой третьей птицы. По-видимому, бактериальная обсемененность различных органов промышленной птицы связана с генерализацией процесса, типичного для бройлеров, что обусловлено сниженной иммунологической резистентностью из-за особенностей их содержания. Доля штаммов АРЕС (avian pathogenic Escherichia coli) в общем микробном составе не изменялась, тогда как протея - увеличилась, а сальмонелл - снизилась, частота других представителей статистически значимо не различалась. Выявлены разнонаправленные тенденции в распространенности антибиотикоустойчивых культур E. coli. Возросло число штаммов, резистентных к ципрофлоксацину, и снизилась доля резистентных к амикацину. Антибиотикоустойчивость бактерий (бактериальный фактор) и иммунологическая супрессия (макроорганизменный фактор) способствовали генерализации коли-инфекции: показатели бактериальной обсемененности сердца и селезенки по сравнению с предыдушим периодом были достоверно выше. Из изученных ветеринарных антибактериальных препаратов Колифлокс, представленный комбинацией колистина и энрофлоксацина, обладает наибольшей активностью в отношении циркулирующих на предприятии энтеробактерий. Несмотря на то, что эффективность фторхинолоносодержащих препаратов в последние годы снижается, отказ от их использования и замена другими на сегодняшний день, по-видимому, нецелесообразны. Полученные данные подтверждают необходимость систематического контроля за наличием возбудителей бактериальных инфекций на предприятиях птицеводства и распространением их антибиотикоустойчивости, что будет способствовать адекватному и эффективному использованию противомикробных средств в ветеринарной практике.

\footnotetext{
ФГБОУ ВО Пермский государственный медицинский университет им. академика Е.А. Вагнера Минздрава России,

614990 Россия, Пермский край, г. Пермь, ул. Петропавловская, 26, e-mail:mar@iegm.ru凶, lizavika@mail.ru, pokatilovamery@gmail.com, aakry@mail.ru, eduard.Gorovitz@mail.ru
}

Sel'skokhozyaistvennaya biologiya [Agricultural Biology], 2019, V. 54, № 4, pp. 754-766

Поступила в редакцию 31 января 2019 года 


\title{
ISOLATED FROM BROILERS IN A POULTRY FARM OF PERM KRAI: A 14-YEAR STUDY
}

\author{
M.V. Kuznetsova, E.V. Afanasievskaya, M.O. Pokatilova, A.A. Kruglova, E.S. Gorovitz
}

Wagner Perm State Medical University, 26, ul. Petropavlovskaya, Perm, 614990 Russia, e-mail mar@iegm.ru ( corresponding author), lizavika@mail.ru, pokatilovamery@gmail.ru, aakry@mail.ru, eduard.Gorovitz@mail.ru ORCID:

Kuznetsova M.V. orcid.org/0000-0003-2448-4823

Afanasyevskaya E.V. orcid.org/0000-0002-3498-6459

Kruglova A.A. orcid.org/0000-0003-4556-1162

Pokatilova M.O. orcid.org/0000-0001-5564-248X

Gorovitz E.S. orcid.org/0000-0003-4320-8672

The authors declare no conflict of interests

Acknowledgements:

Supported financially by the Government of Perm Krai (grant No. C-26/792)

Received January 31, 2019

doi: 10.15389/agrobiology.2019.4.754eng

Sanitary and anti-epizootic measures in poultry industry should restrict spread and circulation of antibiotic-resistant bacteria, including pathogens which are the causative agents of epidemic diseases. This paper is our first report on prevalence and antibiotic resistance of enterobacteria in a commercial poultry flock population during a 14-year period with an assessment of the effectiveness of the most common fluoroquinolone- and colistin-containing veterinary medicines. Our goal was to compare species diversity and the antibiotic resistance of enterobacterial strains isolated from cross Ross 308 broiler chickens (Gallus gallus) in a large poultry complex (JSC PRODO Perm Poultry Farm, Perm Krai). Dead embryos and trachea, lungs, heart, liver, spleen, femur and tibia bones collected from slaughtered broilers were the pathomaterial (995 samples in 2004-2009, and 991 samples in 2010-2017). The organs of healthy broilers served as a control. In special experiments, we assessed the effectiveness of veterinary drugs used against certain pathogens. It was found that the frequency of Enterobacteriaceae family members remained stably high during the whole observation and significantly exceeded that of gram-positive microorganisms ( $p<0.00001)$. In 2010-2017, bacterial contamination was higher in heart $(\mathrm{p}<0.05)$ and spleen $(\mathrm{p}<0.01)$, while the rate of infected dead embryos averaged $25 \%$ and was lower $(\mathrm{p}<0.05)$ compared to 2004-2009. Escherichia coli dominated, and Proteus mirabilis was a subdominant species. The prevalence of avian pathogenic E. coli (APEC) in the microbial community did not change, Proteus isolates $(\mathrm{p}<0.0001)$ increased, and salmonella decreased $(\mathrm{p}<0.05)$, the prevalence of other enterobacteria did not differ significantly. The prevalence of antibiotic-resistant $E$. coli was multidirectional: the ciprofloxacin-resistant strains increased from 47.4 to $75.9 \%$ ( $p<0.0005)$, whereas the amikacin-resistant strains decreased from 32.8 to $16.4 \%$ ( $\mathrm{p}<0.0001$ ). It was shown that Coliflox (NEC Agrovetszashchita SP, LLC, Russia) which contains maximum dosage of colistin and enrofloxacin is the most active among four studied colistin-containing medicines. Further down medicines are Vitrocil (Interchemie werken De Adelaar BV, Netherlands), which contains 10 times less colistin and 2 times less enrofloxacin, Pulmosol $^{\circledR}$ (VIK - Animal Health LLC, Belarus) and Aquaprim (SP Veterinaria, SA, Spain) with 1.1 million and 400,000 IU colistin, respectively. Pulmosol ${ }^{\circledR}$ and Aquaprim, lacking of fluoroquinolones, showed the least activity (37.5 and $35.7 \%$ of resistant $E$. coli, respectively, and 50.0 and $37.5 \%$ of resistant Proteus spp.). Thus, combined veterinary medicines containing enrofloxacin had the highest activity against enterobacteria, but the effectiveness of these drugs has decreased in recent years. The long-term use of fluoroquinolones as dietary additives to prevent infections among poultry seems to be a risk factor leading to the selection of resistant strains.

Keywords: poultry farms, monitoring, enterobacteria, Escherichia coli, antibiotic resistance.

\section{REFEREN CES}

1. Fisinin V.I. V sbornike: 25 let na blago promyshlennogo ptitsevodstva [In: 25 years for industrial poultry]. St. Petersburg, 2015: 3-11 (in Russ.).

2. Linton A.H., Howe K., Bennett P.M., Richmond M.H., Whiteside E.J. The colonization of the human gut by antibiotic resistant Escherichia coli from chickens. Journal of Applied Microbiology, 1977, 43(3): 465-469 (doi: 10.1111/j.1365-2672.1977.tb00773.x).

3. Bazarbaev S.B., Lyapokhov G.V., Belousov V.I. Problemy veterinarnoi sanitarii, gigieny $i$ ekologii, 2016, 1(17): 23-27 (in Russ.).

4. Folorunso O.R., Kayode S., Onibon V.O. Poultry farm hygiene: microbiological quality assessment of drinking water used in layer chickens managed under the battery cage and deep litter systems at three poultry farms in southwestern Nigeria. Pakistan Journal of Biological Sciences, 2014, 17(1): 74-79 (doi: 10.3923/pjbs.2014.74.79).

5. Rozhdestvenskaya T.N., Yakovlev S.S., Kononenko E.V. Farm Animals, 2012, 1(1): 54-56 (in Russ.). 
6. Borisenkova A.N., Korovin R.N., Novikova O.B. RatsVetInform, 2003, 10: 3-6 (in Russ.).

7. Walker S.E., Sander J.E., Cline J.L. Characterization of Pseudomonas aeruginosa isolates associated with mortality in broiler chicks. Avian Diseases, 2002, 46(4): 1045-1050 (doi: 10.1637/0005-2086(2002)046[1045:COPAIA]2.0.CO;2).

8. Wilson I.G. Antimicrobial resistance of Salmonella in raw retail chickens, imported chicken portions, and human clinical specimens. Journal of Food Protection, 2004, 67(6): 1220-1225 (doi: 10.4315/0362-028X-67.6.1220).

9. Parmley E.J., Pintar K., Majowicz S., Avery B., Cook A., Jokinen C., Gannon V., Lapen D.R., Topp E., Edge T.A., Gilmour M., Pollari F., Reid-Smith R., Irwin R.A Canadian application of one health: integration of Salmonella data from various Canadian surveillance programs (20052010). Foodborne Pathogens and Disease, 2013, 10(9): 747-756 (doi: 10.1089/fpd.2012.1438).

10. Miles T.D., McLaughlin W., Brown P.D. Antimicrobial resistance of Escherichia coli isolates from broiler chickens and humans. BMC Veterinary Research, 2006, 2(1): 7 (doi: 10.1186/17466148-2-7).

11. Koga V.L., Rodrigues G.R., Scandorieiro S., Vespero E.C., Oba A., de Brito B.G., de Brito K.C., Nakazato G., Kobayashi R.K. Evaluation of the antibiotic resistance and virulence of Escherichia coli strains isolated from chicken carcasses in 2007 and 2013 from Parana, Brazil. Foodborne Pathogens and Disease, 2015, 12(6): 479-485 (doi: 10.1089/fpd.2014.1888).

12. Muhammad M., Muhammad L.U., Ambali A.G., Mani A.U., Azard S., Barco L. Prevalence of Salmonella associated with chick mortality at hatching and their susceptibility to antimicrobial agents. Veterinary Microbiology, 2010, 140(1-2): 131-135 (doi: 10.1016/j.vetmic.2009.07.009).

13. Medeiros M.A.N., de Oliveira D.C.N., dos Prazeres Rodrigues D., de Freitas D.R.C. Prevalence and antimicrobial resistance of Salmonella in chicken carcasses at retail in 15 Brazilian cities. Revista Panamericana de Salud Publica, 2011, 30(6): 555-560 (doi: 10.1590/s102049892011001200010).

14. Hofacre C.L., de Cotret A.R., Maurer J.J., Garrity A., Thayer S.G. Presence of fluoroquinolone resistant coliforms in poultry litter. Avian Diseases, 2000, 44(4): 963-967 (doi: 10.2307/1593073).

15. Alvarez-Fernandez E., Alonso-Calleja C., Garcia-Fernandez C., Capita R. Prevalence and antimicrobial resistance of Salmonella serotypes isolated from poultry in Spain: comparison between 1993 and 2006. International Journal of Food Microbiology, 2012, 153(3): 281-287 (doi: 10.1016/j.ijfoodmicro.2011.11.011).

16. Kuznetsova M.V., Karpunina T.I., Pospelova S.V., Afanas'evskaya E.V., Gorovits E.S., Demakov V.A. Vestnik NGU. Seriya: Biologiya, klinicheskaya meditsina, 2010, 8(3): 70-77 (in Russ.).

17. Mellata M. Human and avian extraintestinal pathogenic Escherichia coli: infections, zoonotic risks, and antibiotic resistance trends. Foodborne Pathogens and Disease, 2013, 10(11): 916-932 (doi: 10.1089/fpd.2013.1533).

18. Malinin M.L., Tikhomirova E.I., Gabalov K.P. Fundamental'nye issledovaniya, 2009, 4: 34-38 (in Russ.).

19. Skora J., Matusiak K., Wojewodzki P. Nowak A., Sulyok M., Ligocka A., Okrasa M., Hermann J., Gutarowska B. Evaluation of microbiological and chemical contaminants in poultry farms. International Journal of Environmental Research and Public Health, 2016, 13(2): 192 (doi: 10.3390/ijerph13020192).

20. Kozhemyaka N. Zhivotnovodstvo Rossii, 2008, 11: 15-16 (in Russ.).

21. Novikova O.B., Bartenev A.A. Sovremennye tendentsii razvitiya nauki i tekhnologii, 2015, 8(4): 35-37 (in Russ.).

22. Lysko S.B., Makarova O.A. Materialy Mezhdunarodnoi nauchno-prakticheskoi konferentsii «Ptakhivnitstvo-2009» [Proc. Int. Conf. «Poultry Farming 2009»]. Khar'kov, 2009, vyp. 62: 109-111.

23. Fotina A.A., Klischova Zh.E. The sensitivity of the pathogens of poultry's bacterial diseases to antibiotics. Scientific Messenger of LNU of Veterinary Medicine and Biotechnologies. Series: Veterinary Sciences, 2016, 18(3/71): 182-185 (doi: 10.15421/nvlvet7141).

24. Barnes H.J., Vaillancourt J.P., Gross W.B. Colibacillosis. In: Diseases of poultry, 11th Edition. Y.M. Saif, H.J. Barnes, A.M. Fadly, J.R. Glisson, L.R. McDougald, D.E. Swayne (eds.). Iowa State Press, Iowa City, IA: 631-656.

25. Kalinin A.N., Rozhdestvenskaya T.N., Kononenko E.V. V sbornike: 25 let na blago promyshlennogo ptitsevodstva [In: 25 years for industrial poultry]. St. Petersburg, 2015: 14-18 (in Russ.).

26. Thorsteinsdottir T.R., Haraldsson G., Fridriksdottir V., Kristinsson K.G., Gunnarsson E. Prevalence and genetic relatedness of antimicrobial-resistant Escherichia coli isolated from animals, foods and humans in Iceland. Zoonoses and Public Health, 2010, 57(3): 189-196 (doi: 10.1111/j.1863-2378.2009.01256.x).

27. Talebiyan R., Kheradmand M., Khamesipour F., Rabiee-Faradonbeh M. Multiple antimicrobial resistance of Escherichia coli isolated from chickens in Iran. Veterinary Medicine International, 2014: 1-4 (doi: 10.1155/2014/491418).

28. Boulianne M., Arsenault J., Daignault D., Archambault M., Letellier A., Dutil L. Drug use and 
antimicrobial resistance among Escherichia coli and Enterococcus spp. isolates from chicken and turkey flocks slaughtered in Quebec, Canada. Canadian Journal of Veterinary Research, 2016, 80(1): 49-59.

29. Nelson J.M., Chiller T.M., Powers J.H., Angulo F.J. Fluoroquinolone-resistant Campylobacter species and the withdrawal of fluoroquinolones from use in poultry: a public health success story. Clinical Infectious Diseases, 2007, 44(7): 977-980 (doi: 10.1086/512369).

30. Perrin-Guyomard A., Bruneau M., Houée P., Deleurme K., Legrandois P., Poirier C., Soumet C., Sanders P. Prevalence of $m c r-1$ in commensal Escherichia coli from French livestock, 2007 to 2014. Eurosurveillance, 2016, 21(6): 30135 (doi: 10.2807/1560-7917.ES.2016.21.6.30135). 